\title{
Assessing effectiveness of the blue crab spawning stock sanctuary in Chesapeake Bay using tag-return methodology
}

\author{
Debra M. Lambert, Romuald N. Lipcius* ${ }^{*}$ John M. Hoenig \\ Virginia Institute of Marine Science, The College of William and Mary, PO Box 1346, Gloucester Point, Virginia 23062, USA
}

\begin{abstract}
The blue crab spawning stock in Chesapeake Bay sustained a severe and persistent decline beginning in 1992. As part of the effort to enhance the spawning stock, the spawning sanctuary in lower Chesapeake Bay was enlarged to over 240000 ha. This marine reserve and corridor prohibits exploitation of mature females en route to or in the spawning grounds during the summer spawning season (1 June to 15 September). To assess the effectiveness of the sanctuary, we tagged terminally molted, mature females inside and outside the sanctuary during 3 sanctuary seasons (2002 to 2004). Crabs were captured throughout the bay and its tributaries, measured, tagged, and released on site. Recaptures of tagged crabs were reported by commercial and recreational fishers. Probability of recapture for crabs released outside the sanctuary was $6.3,5.2$, and 2.8 times the probability of recapture for crabs tagged inside the sanctuary in 2002, 2003 and 2004, respectively. Consequently, a significant proportion of adult female blue crabs remains in the sanctuary to spawn and is not captured by the fishery. Hence, the marine reserve and corridor for the blue crab spawning stock in Chesapeake Bay is an effective means of protecting females migrating to or residing in the spawning grounds. This investigation serves as one of the few empirical tests to date of the effectiveness of a marine reserve designed to protect spawning stock.
\end{abstract}

KEY WORDS: Blue crab $\cdot$ Callinectes sapidus $\cdot$ Spawning sanctuary $\cdot$ Marine reserve $\cdot$ Tag-return

\section{INTRODUCTION}

\section{Spawning sanctuaries}

One of the main objectives of marine reserves, 'a zone in which some or all of the biological resources are protected from removal or disturbance' (National Research Council 2001), is the protection of spawningstock biomass to provide a source of recruitment to fisheries outside the reserve via larval dispersal (Roberts \& Polunin 1991, Dugan \& Davis 1993, Rowley 1994). Assessment of the effectiveness of marine reserves is important to improve the design, use and management of reserve systems. Assessment typically involves definition of the goals and objectives of the reserve, collection of data on various measurable indicators of success, and evaluation to determine whether the reserve is meeting the intended goals and objectives.

Empirical evidence for the efficacy of reserves that specifically target the spawning stock is extremely limited. The presumption that spawning stock reserves will increase recruitment in nearby areas is often not valid (Kassner \& Malouf 1982, Heslinga et al. 1984, McCay 1988), probably due to various biotic and physical processes critical to enhancing recruitment at the metapopulation level (Lipcius et al. 2005). Examples of effective marine reserves do exist, however. Spawning stock abundance and potential egg production were higher inside than outside reserves for the Caribbean spiny lobster Panulirus argus (Bertelsen \& Cox 2001, Lipcius et al. 2001a), the American lobster Homarus americanus (Rowe 2002), and the Nassau grouper Epinephelus striatus (reviewed in Chiappone \& Sealey 
2000), which were most likely linked to the higher abundance and larger sizes of animals in reserves. Although it is uncertain whether an increase in egg production or spawning stock abundance will lead to an increase in recruitment, these studies suggest the feasibility of protecting a portion of the spawning stock in reserves to enhance egg production of marine metapopulations.

The transplanting of adult animals into favorable habitats with the goal of increasing recruitment has been attempted with several invertebrates and provides an additional example of a spawning stock reserve. The transplanting of hard clams Mercenaria mercenaria was deemed ineffective when clam abundance, survival, and gamete production of the transplanted clams were low (McCay 1988) or when contribution to larval production and recruitment was low (Kassner \& Malouf 1982). The transplanting of Eastern oyster Crassostrea virginica onto no-take oyster reefs has seen occasional success throughout Chesapeake Bay, as spat settlement has increased on some stocked reefs and nearby oyster grounds following stocking efforts (Southworth \& Mann 1998, Brumbaugh et al. 2000). Low mortality and evidence of reproduction, based on a visual index of gonadal bulk, of transplants and large numbers of apparent recruits suggest that the transplanting of green abalone Haliotis fulgens can be effective in enhancing populations (Tegner 1992). The translocation of non-spawning adult queen conch Strombus gigas to offshore sites, where spawning occurs, has proven to be a feasible means of augmenting the spawning stock (Delgado et al. 2004).

The protection of spawning aggregations is another means of using marine reserves to protect spawning stock. Since spawning aggregations are often predictable and targeted by fishers, they are susceptible to overexploitation. In some cases, protection of spawning aggregations has increased density, biomass and individual size of various grouper species (Beets \& Friedlander 1992, 1998, Chiappone et al. 2000). Protection of spawning aggregations has also resulted in a more favorable sex ratio in the red hind Epinephelus guttatus (Beets \& Friedlander 1992, 1998), gag Mycteroperca microlepis, and scamp M. phenax (Coleman et al. 2004).

Tag-return studies, where animals are captured, tagged and released with the hope that they will be recaptured and reported at some future date by the commercial or recreational fishery, have been used to assess the movement of animals in relation to marine reserves. Tag-return data can be used to estimate emigration rates of animals from reserves (Attwood \& Bennett 1994, McGarvey 2004), to demonstrate the movement of juveniles away from protected nursery habitats into areas open to exploitation (Davis \&
Dodrill 1980, 1989, Gitschlag 1986), and to compare recapture rates between animals tagged inside and outside of reserves (Rowe 2001, Medici 2004). When tag-return studies are conducted concurrently in areas open to fishing and in marine reserves, patch-specific mortality rates can be estimated (Joe 2001).

\section{Blue crab Callinectes sapidus}

Mature female blue crabs are ideal for tag-return studies because they do not molt (Churchill 1919, Van Engel 1958) so tag loss is likely to be minimal. The shape of the carapace is such that a lightweight and non-invasive tag can easily be attached around the lateral spines on the dorsal surface. Tag-return studies on the blue crab have been used to examine migration (Fiedler 1930, Cronin 1949, Fischler \& Walburg 1962, Tagatz 1968, Judy \& Dudley 1970, Oesterling 1976, McConaugha 1993, Turner et al. 2003, Aguilar et al. 2005), to provide estimates of population size (Fischler 1965), and to assess the effectiveness of protected areas (Medici 2004). It was the objective of this study to use tag-return methodology with adult female blue crabs in Chesapeake Bay to assess the effectiveness of the Virginia blue crab spawning sanctuary.

The blue crab fishery is the most important commercial fishery in Chesapeake Bay (Rugolo et al. 1998, Anonymous 2003), yet spawning stock biomass has declined by $84 \%$ relative to levels in the late 1980s (Lipcius \& Stockhausen 2002). The life cycle of the blue crab in Chesapeake Bay involves a terminal molt of the females and subsequent mating between early May and October, with peaks in May and late August or early September (Van Engel 1958, Millikin \& Williams 1984). After maturing and mating, female crabs migrate to the higher salinity waters of the southern part of Chesapeake Bay either to spawn or to overwinter and spawn the following year (Churchill 1919, Van Engel 1958). Spawning occurs between May and early September (Van Engel 1958, Jones et al. 1990, Prager 1996).

\section{History of the blue crab sanctuary}

One approach to managing the blue crab stock in Chesapeake Bay involves a marine reserve. A spawning sanctuary established in the southern part of the bay in 1942 was originally 37814 ha (Rob O'Reilly, Virginia Marine Resources Commission (VMRC), pers. comm.) and closed to the crab fishery during July and August (Sandoz 1943). The sanctuary was originally implemented in response to a significant decline in blue crab harvest throughout Chesapeake Bay in 1940 
and 1941 and was established to protect adult female blue crabs during the spawning period (Sandoz 1943). The sanctuary season was extended to include April, May, and June in 1943 (Sandoz 1943). Initial investigations deemed the historical sanctuary effective due to high densities of blue crab zoeae (Sandoz 1943, Newcombe 1943), migration of egg-bearing female crabs (Sandoz 1943, Newcombe 1943), and optimal environmental conditions for embryonic and larval development (Sandoz \& Rogers 1944) in the sanctuary area. In addition, our evaluation of data from a previous tagreturn study (McConaugha 1993) indicated that adult female crabs tagged within the historical sanctuary were not captured by the fishery. The historical sanctuary, however, did not protect a sufficiently large fraction of the spawning stock (Seitz et al. 2001) to avert an $84 \%$ decrease in overall spawning stock biomass (Lipcius \& Stockhausen 2002).

It is not known when the sanctuary season switched to the present day period of 1 June to 15 September. Both recreational and commercial crab harvesting are prohibited in the sanctuary area, except that recreational crabbing is lawful in the lower sanctuary area (Code of Virginia). The size of the sanctuary has increased considerably over the last 12 yr. In 1994, the Bayside Eastern Shore Sanctuary (BESS) was established to include an additional 19400 ha of protected waters in the bay along the eastern shore of the lower bay, which was later reduced to 16000 ha in 1998 when the upper portion was removed and opened to fishing (Seitz et al. 2001). Approximately $16 \%$ of the potential spawning stock was protected by the historical sanctuary and BESS (Seitz et al. 2001). Lipcius et al. (2001b) studied the potential for an expanded sanctuary in protecting adult female crabs migrating to the spawning grounds in the lower bay. They found catch per unit effort (CPUE) of adult females in a fishery independent trawl survey was significantly higher in the proposed deepwater marine reserve and corridor (>13 $\mathrm{m}$ depths) than in adjacent shallow water, suggesting that expansion of the existing sanctuary into deeper waters would further protect the spawning stock.

In June 2000, the sanctuary was expanded from the mouth of the bay to the Virginia/Maryland border, roughly following the $10.7 \mathrm{~m}$ depth contour in the mainstem of the bay, to a size of 172235 ha (Lipcius et al. 2003). The purpose of the expansion was not only to protect the female crabs in the spawning grounds but also to protect adult females en route to the spawning grounds during the reproductive period. Approximately $50 \%$ of the adult females sampled by Lipcius et al. (2003) occurred in waters deeper than $10 \mathrm{~m}$ and were therefore protected by the spawning sanctuary. The Virginia blue crab sanctuary was enlarged again in 2002, roughly following the $9.1 \mathrm{~m}$ depth contour, to its current size of 240092 ha. The enlarged sanctuary is estimated to protect $70 \%$ of the adult females (i.e. spawning stock) in lower Chesapeake Bay during the spawning season (Lipcius et al. 2003). The effectiveness of the sanctuary, however, has not been tested.

The objective of the blue crab sanctuary is to protect females in and en route to the spawning grounds in the reproductive period, with the overall goal of increasing spawning potential. The effectiveness of the sanctuary in protecting the blue crab is in part determined by the degree and nature of crabs' mobility relative to the size and shape of the sanctuary. The effectiveness of the sanctuary is dependent on female crabs remaining in the sanctuary for spawning, and would be reduced if females were to move outside of the sanctuary prior to spawning and be captured by the fishery. To assess the effectiveness of the spawning sanctuary, mature females were tagged and released inside and outside of the sanctuary in the summers of 2002, 2003, and 2004. A comparison of the probability of recapture for crabs tagged outside the sanctuary to crabs tagged inside the sanctuary using relative risk provided a means of assessing sanctuary effectiveness quantitatively.

\section{MATERIALS AND METHODS}

Tagging and tag return. Mature female crabs were obtained from the Virginia Institute of Marine Science (VIMS) Trawl Survey, Maryland Department of Natural Resources (MDNR) Trawl Survey, and VIMS Chesapeake Bay Multispecies Monitoring and Assessment Program (ChesMMAP) between 1 June and 15 July of 2002, 2003, and 2004. The University of Maryland Chesapeake Biological Laboratory's (CBL) Chesapeake Bay Fishery Independent Multispecies Fisheries Survey (CHESFIMS) also obtained crabs in 2004. Crabs were measured (carapace width, spine to spine) with vernier calipers and tagged by tying a strap tag across the back and around the lateral spines (Fig. 1); the ends were crimped together with a $0.635 \mathrm{~cm}$, zinc-plated copper, oval sleeve (mean weight of tag and crimp $=1.27 \pm 0.06$ (SD) g). Crabs were then released as close as possible to the capture location (see Figs. 3 \& 4). The number of tagged crabs released at each site was proportional to the number caught at the site, which helped ensure that the distribution of tagged crabs was representative of the distribution of mature females. Each tag had an individual identification number, a toll-free phone number, the words '\$20 REWARD' and instructions to record the location and date of capture. An informational flyer was sent in February 2004 to all licensed crab fishers in Virginia to inform them of the tagging program. News- 


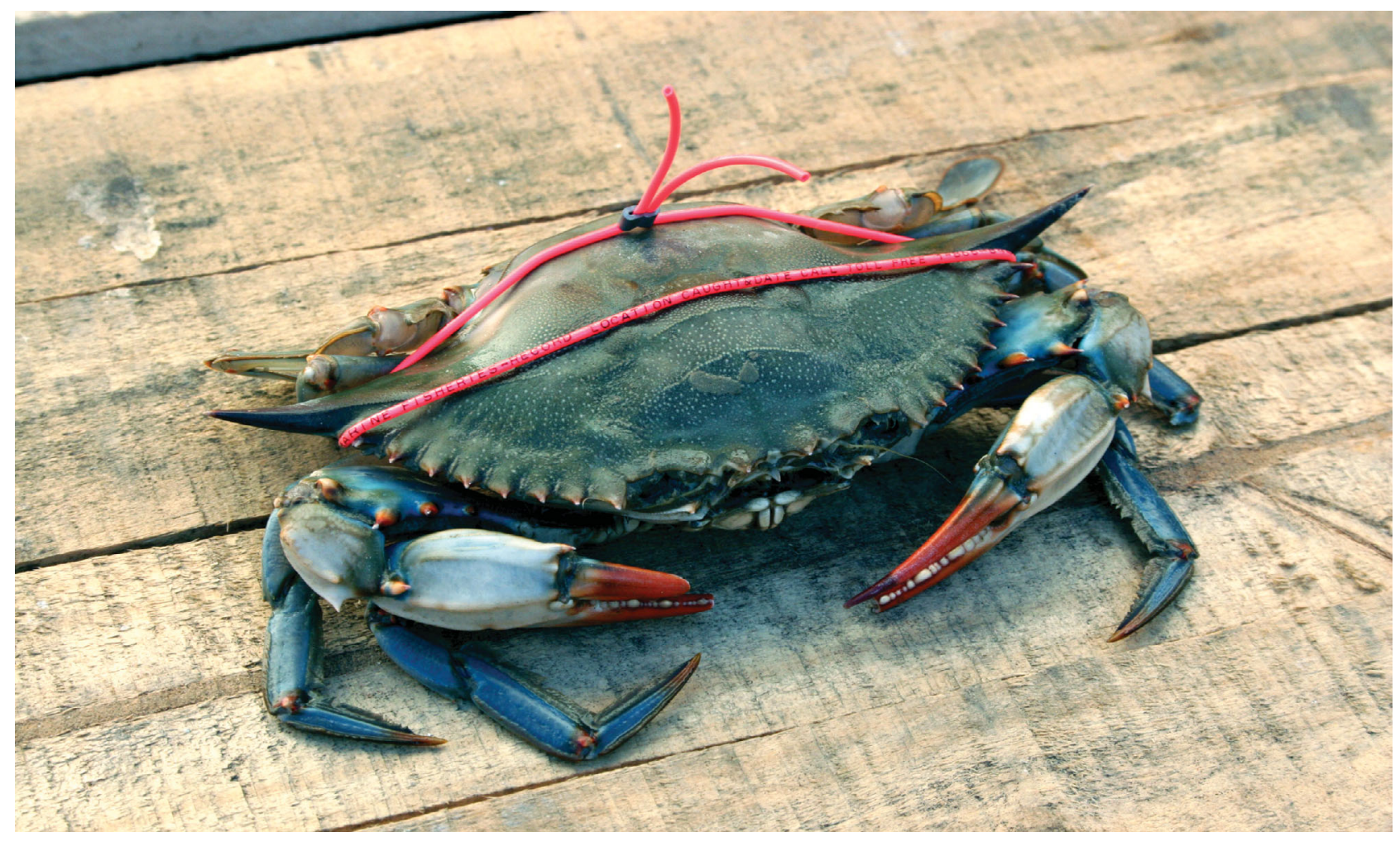

Fig. 1. Callinectes sapidus. Mature female with tag attached

paper articles in the Waterman's Gazette (published by the Maryland Watermen's Association) also publicized the program regularly from July 2004.

Captures of tagged crabs were reported by commercial and recreational fishers, who captured the tagged crabs during normal fishing operations. We obtained as much of the following information from the fishers as possible: location of capture, date of capture, water depth, method of capture, presence or absence of an egg mass, and whether the fisher was commercial or recreational. A letter describing the program with the corresponding crab release information, a data sheet, a map of Chesapeake Bay, and a self-addressed stamped envelope were mailed to the fisher with instructions to make any additional comments, to mark the location of the capture, and to return the data forms and tag back to VIMS. Once the tag was received, payment was mailed to the fisher.

Survey design. Crabs were obtained and tagged by the following 4 fishery-independent trawl surveys to extend our tagging effort over a wide area (Chesapeake Bay and tributaries). The VIMS Trawl Survey operates in the Virginia portion of Chesapeake Bay and in the James, York, and Rappahannock Rivers. The survey deploys a $9.14 \mathrm{~m}$ semi-balloon otter trawl and tows for 5 min at approximately 100 sites monthly according to a combined fixed and stratified random sampling design (Montane et al. 2004). The MDNR Trawl Survey samples 37 fixed sites in 6 river systems (Chester River, Eastern Bay, Choptank River, Patuxent River, Tangier Sound, and Pocomoke Sound) and 12 trial sites in 3 river systems (Fishing Bay, Little Choptank, and Nanticoke) monthly from May through October using a $4.9 \mathrm{~m}$ semi-balloon otter trawl (L. Fegley, MDNR, pers. comm.). The VIMS ChesMMAP survey samples the entire mainstem of Chesapeake Bay, stratifying the Bay into 5 regions with 3 depth strata per region. The survey deploys a $13.7 \mathrm{~m}$ otter trawl and tows at approximately 3.5 knots for 20 min per site. Five cruises are conducted each year (March, May, July, September, and November) and approximately 80 to 90 sites are sampled per cruise (Latour et al. 2003, Bonzek et al. 2004). The CHESFIMS survey of CBL conducts 3 cruises a year (spring, summer, and fall) and samples approximately 50 sites per cruise throughout the mainstem of Chesapeake Bay according to a combined fixed and stratified random sampling design. The survey uses a single, oblique stepped midwater trawl $\left(18 \mathrm{~m}^{2}\right)$ (Miller et al. 2005).

Recapture probability. The effectiveness of the sanctuary was characterized by comparing the probability of recapture for crabs tagged outside the sanctuary to the probability of recapture for crabs tagged inside the sanctuary using relative risk (Daniel 1999). 
Only crabs tagged between 1 June and 15 July and then subsequently recaptured between 1 June and 15 September (the time period that the sanctuary is in effect) were considered for this analysis. During this time period, crab harvesting (and therefore the recapture of a tagged crab) can occur anywhere in the bay, except for the sanctuary.

Relative risk (RR) is a ratio of 2 probabilities and is calculated by $\mathrm{p}_{i}: \mathrm{p}_{j}$, where $\mathrm{p}_{i}$ and $\mathrm{p}_{j}$ are the proportions of the animals in groups $i$ and $j$ that are recaptured; $i$ and $j$ take on the values 'tagged outside' and 'tagged inside', respectively. The $95 \%$ confidence interval for the relative risk is calculated by:

$$
R R^{1 \pm\left(z_{\alpha} / \sqrt{\chi^{2}}\right)}
$$

where $z_{\alpha}$ is the 2-sided $z$ value corresponding to the chosen confidence interval $(z=1.96)$ and $\chi^{2}$ is the chi square test statistic (Daniel 1999). The $\chi^{2}$ value derived from a $2 \times 2$ contingency table (comparing frequency of tagged crabs that are recaptured and not recaptured within the sanctuary and outside of the sanctuary) can be calculated by the shortcut formula:

$$
\frac{n(a d-b c)^{2}}{(a+c)(b+d)(a+b)(c+d)}
$$

where $n$ is the total number of crabs tagged, and $a, b$, $c_{1} d$ are the number of crabs tagged outside and recaptured, number of crabs tagged outside and not recaptured, number of crabs tagged inside and recaptured, and number of crabs tagged inside and not recaptured, respectively (Daniel 1999). The null hypothesis is that tag recapture and location of release (inside vs. outside of the sanctuary) are independent. A relative risk of one indicates that the probability of recapture is the same for both groups of crabs, whereas a relative risk greater than 1 implies that the probability of recapture for crabs tagged outside is greater than that for crabs tagged inside.

The shortest in-water distance between release location and the sanctuary border was estimated using Arcview GIS software for each crab tagged and recaptured. Data were pooled across all years and probability of recapture was plotted against distance to sanctuary border at release for crabs tagged inside and outside of the sanctuary. This was conducted to determine if all crabs within an area, either inside or outside of the sanctuary, are equally likely to be recaptured regardless of the distance to the sanctuary border. The analysis for crabs released inside the sanctuary tests the biological hypothesis that crabs released close to the sanctuary border are more likely than those tagged deep within the sanctuary to be recaptured either by illegal fishing in the sanctuary or by moving outside the sanctuary and being recaptured legally. The analysis for crabs released outside of the sanctuary tests the biological hypothesis that crabs released closer to the sanctuary are more likely to move inside the sanctuary and are therefore less likely to be recaptured than those tagged far from the sanctuary.

Movement, distance traveled, and days at large. The recapture locations of crabs recaptured during the sanctuary period (1 June to 15 September) were plotted using Arcview GIS software based on the location description provided by the fisher. Recapture locations are approximations as specific coordinates were rarely provided. Migration of crabs was assessed qualitatively by plotting straight lines between release and recapture locations. The shortest possible in-water distance between release location and recapture location was estimated using Arcview GIS software. These distances were likely underestimates of the actual distances traveled. The number of days at large (the number of days between release and subsequent recapture) was calculated for all recaptured crabs. Data were pooled from the $3 \mathrm{yr}$, due to low sample size; mean distance traveled and mean number of days at large were calculated for crabs released inside and outside the sanctuary. Unpaired $t$-tests were conducted to determine if mean distance traveled and mean days at large varied with release location (inside vs. outside the sanctuary).

Size. The mean sizes (mm carapace width) of crabs tagged inside and outside of the spawning sanctuary during each year were compared using unpaired $t$-tests. To test at a nominal $\alpha=0.05$, the individual tests were conducted at a Bonferroni-corrected $\alpha=0.05 / 3=$ 0.017 . In addition, size data over all years and both tagging locations were pooled, due to low sample size, before the mean sizes of crabs (recaptured or not recaptured) were compared by means of an unpaired $t$-test.

\section{RESULTS}

\section{Recapture probability}

A total of 843 crabs was released between 1 June and 15 July of 2002, 2003 and 2004, of which 104 individuals were recaptured during the time period of the sanctuary (1 June to 15 September). The majority of recaptures $(92 \%)$ was reported by commercial fishers, of which $94 \%$ was recaptured in crab pots, $5 \%$ by trot line, and $1 \%$ within pound nets. The remaining $8 \%$ of recaptures was reported by recreational fishers. Two of the commercial recaptures were reported by seafood processing facilities rather than by individual fishers.

Crabs tagged outside the sanctuary had significantly higher probabilities of recapture than those tagged 
inside the sanctuary in 2002 ( $R R=6.3,95 \%$ CI 2.4 to 16.3) and 2004 ( $R R=2.8,95 \%$ CI 1.6 to 5.0) (Table 1). An increased risk of recapture was also detected in $2003(\mathrm{RR}=5.2,95 \%$ CI 0.9 to 29.0), although this result was marginally significant (Table 1). For all $3 \mathrm{yr}$, the percentage recaptured was much higher for crabs released outside of the sanctuary than for crabs released inside the sanctuary, ranging from 12 to $21 \%$ outside the sanctuary and from 2 to $6 \%$ inside the sanctuary (Table 1). There was no apparent relationship between distance to the sanctuary border and the probability of recapture for crabs released either inside or outside of the sanctuary (Fig. 2).

Ideally, all tag releases would have occurred on the first day that the sanctuary was imposed (1 June) in each year. Since this was not logistically possible, the releases occurred over a longer time 'window'. This introduces some bias since crabs that are released first will experience higher fishing mortality than those released later. Crabs released towards the end of the sanctuary season (i.e. in late August and September) would be less likely to be recaptured during the time period of the sanctuary, regardless of release location, simply because they are at large for a shorter time period. An analysis of the relative risk of recapture using different periods of release window length (possible as additional crabs were tagged after July 15 for another study) showed that the relative risk did not change substantially. We chose crabs tagged between 1 June and 15 July in our analysis because this time window for crab releases was short enough to reduce the potential for bias but at the same time provided an adequate sample size. In addition, there was no difference between the time windows of crab releases inside and outside of the sanctuary, such that there was no bias in the relative risk estimates due to these time windows.

Table 1. Callinectes sapidus. Number of adult female blue crabs tagged and recaptured, percent recaptured, relative risk (95\% Confidence Interval), chisquare test statistic $\left(\chi^{2}\right)\left(\chi_{1,0.95}^{2}=3.84\right)$ and corresponding significance levels ( $p$ ) for crabs tagged and released outside and inside spawning sanctuary between 1 June and 15 July and recaptured while sanctuary was in effect

\begin{tabular}{|clcccccc|}
\hline \multirow{2}{*}{ Year } & $\begin{array}{l}\text { Tagging } \\
\text { location }\end{array}$ & $\begin{array}{c}\text { Number } \\
\text { tagged }\end{array}$ & $\begin{array}{c}\text { Number } \\
\text { recaptured }\end{array}$ & $\begin{array}{c}\text { Recaptured } \\
(\%)\end{array}$ & $\begin{array}{c}\text { Relative } \\
\text { risk }\end{array}$ & $\chi^{2}$ & $p$ \\
\hline $\mathbf{2 0 0 2}$ & Outside & 168 & 35 & 21 & $6.3(2.4,16.3)$ & $14.5<0.0005$ \\
& Inside & 91 & 3 & 3 & & & \\
& Total & 259 & 38 & 15 & & & \\
$\mathbf{2 0 0 3}$ & Outside & 125 & 15 & 12 & $5.2(0.9,29.0)$ & 3.5 & 0.06 \\
& Inside & 43 & 1 & 2 & & & \\
& Total & 168 & 16 & 10 & & & \\
$\mathbf{2 0 0 4}$ & Outside & 209 & 37 & 18 & $2.8(1.6,5.0)$ & 12.8 & 0.0003 \\
& Inside & 207 & 13 & 6 & & & \\
& Total & 416 & 50 & 12 & & & \\
\hline
\end{tabular}

\section{Movement, distance traveled, and days at large}

Almost all recaptured crabs were caught at locations downriver or down the bay from their release locations. Crabs released outside the sanctuary moved towards the bay mainstem and the lower bay spawning grounds (Fig.3). Crabs released inside the sanctuary tended to be recaptured in the lower bay spawning grounds and in shallow feeding areas (Fig. 4).

The distance traveled by crabs varied from $<1 \mathrm{~km}$ to $135 \mathrm{~km}$ (mean = $26 \pm 3$ (SE) km, n = 102). No significant difference in distance traveled was detected between crabs released inside (mean $=23 \pm 4(\mathrm{SE}) \mathrm{km}, \mathrm{n}=16)$ and outside (mean $=27 \pm 3(\mathrm{SE}) \mathrm{km}, \mathrm{n}=86)$ the sanctuary ( $t$-test: $\mathrm{df}=100 ; \mathrm{p}=0.596)$.

The overall time at large for crabs recaptured during the sanctuary season varied from 1 to $48 \mathrm{~d}$ (mean $=15.0$ $\pm 1.3(\mathrm{SE}) \mathrm{d}, \mathrm{n}=99$ ). The mean time at large was significantly longer for crabs released inside the sanctuary $(23.2 \pm 3.4(\mathrm{SE}) \mathrm{d}, \mathrm{n}=17)$ than for crabs released outside the sanctuary $(13.4 \pm 1.3(\mathrm{SE}) \mathrm{d}, \mathrm{n}=82)$ ( $t$-test: $\mathrm{df}=97 ; \mathrm{p}=0.003)$.

\section{Size}

The mean sizes (mm carapace width) of females released between 1 June and 15 July outside and inside of the spawning sanctuary differed by less than $3 \mathrm{~mm}$ and were not significantly different in 2002 (Table 2, $t$-test: $\mathrm{df}=193 ; \mathrm{p}=0.719$ ) and 2003 (Table 2, $t$-test: $\mathrm{df}=165 ; \mathrm{p}=0.228)$. The mean size of crabs was significantly larger outside $(148.4 \pm 1.4(\mathrm{SE}) \mathrm{mm}, \mathrm{n}=$ 209) than inside $(138.8 \pm 1.1(\mathrm{SE}) \mathrm{mm}, \mathrm{n}=207)$ the sanctuary in 2004 (Table $2, t$-test: $d f=386$; $\mathrm{p}<0.0005$ ). Over all years and both tagging locations, the mean size of recaptured crabs $(144.7 \pm 1.5(\mathrm{SE}) \mathrm{mm}, \mathrm{n}=101)$ was significantly larger than the mean size of crabs that were not recaptured $(140.8 \pm 0.7(\mathrm{SE}) \mathrm{mm}, \mathrm{n}=677)(t$-test: $\mathrm{df}=776 ; \mathrm{p}=0.035)$.

\section{DISCUSSION}

The effectiveness of marine reserves in protecting mobile species is determined by the degree and nature of their mobility and the size and shape of the reserve. Highly migratory species are more likely to move outside of protected areas and become susceptible to exploitation, such that large reserves are needed (Polacheck 1990, Rowley 1994, Guénette et al. 2000). Female 

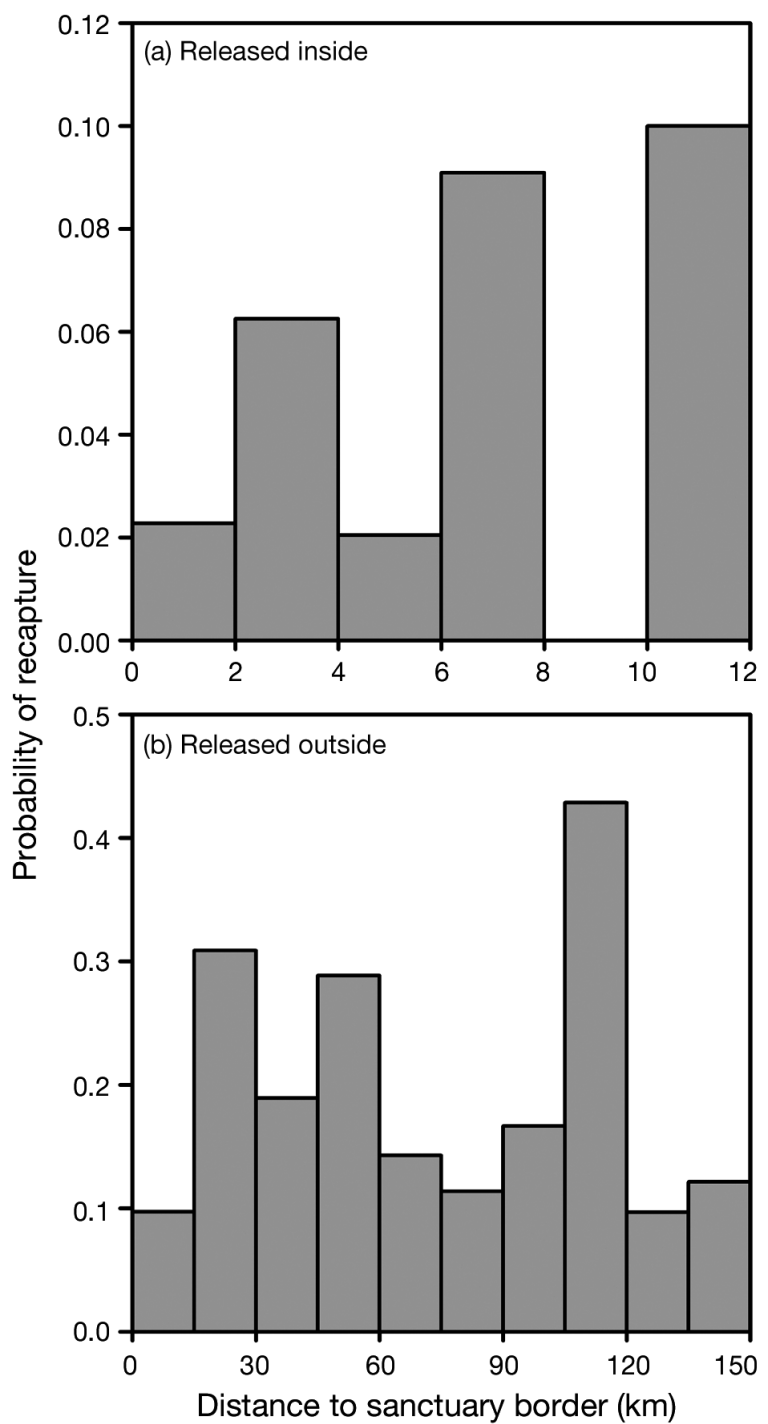

Fig. 2. Callinectes sapidus. Recapture probability of tagged crabs in relation to the distance to sanctuary border at release for crabs released (a) inside and (b) outside spawning sanctuary

blue crabs in Chesapeake Bay migrate up to $200 \mathrm{~km}$ (Fiedler 1930, Hines et al. 1995, Turner et al. 2003, Aguilar et al. 2005, this study) to reach the spawning grounds in the lower portion of the Bay. The blue crab sanctuary encompasses 240092 ha in the mainstem of lower Chesapeake Bay from 1 June to 15 September. The effectiveness of the sanctuary is dependent on female crabs remaining in the sanctuary for spawning, and would be reduced if females were to move outside the sanctuary and be exploited prior to spawning. The probability of recapture was substantially and significantly higher for crabs tagged outside the sanctuary relative to crabs tagged inside the sanctuary during the $3 \mathrm{yr}$ of this study, such that females outside the sanctuary were approximately 3 to 6 times more likely to be caught by fishers than females inside the sanctuary. These findings indicate that the sanctuary is of a sufficient size that most females in the sanctuary do not move out of the sanctuary prior to spawning.

The measure of the effectiveness of the sanctuary using relative risk analysis reflects both movement of crabs and illegal fishing by fishers. An individual tagged inside the sanctuary could be recaptured either outside the sanctuary or by illegal poaching from within the sanctuary. In either of these situations, the sanctuary has not been effective which tends to equalize the catch rates from the 2 areas. There was, however, little evidence for illegal fishing within the sanctuary. We flew over the sanctuary on 2 different dates during the summer of 2002, and observed very few crab pots within sanctuary boundaries. In addition, VMRC reported very few cases of illegal fishing within the sanctuary during their reconnaissance flights over the sanctuary (Col. Steve Bowman pers. comm.).

If illegal fishing did occur, we believe that the incentive of the $\$ 20$ reward together with the fact that a tagged crab recaptured illegally can be reported as a legal catch (i.e. one caught outside the sanctuary), mean that fishers should not be deterred from reporting such recaptures. Moreover, should illegal catches be thus reported, this would not bias our estimate of the relative risk of recapture.

Of 104 crabs recaptured during the sanctuary period (Table 1), 3 were reported recaptured within the sanctuary. These 3 individuals were caught by recreational fishers in the southern portion of the sanctuary where recreational fishing is allowed. A total of 16 crabs were recaptured within $1.5 \mathrm{~km}$ of the sanctuary border. Since recapture locations are approximations, it is difficult to know for certain on which side of the sanctuary border these crabs were recaptured. Uncertainty of recapture location does not, however, affect our estimate of the relative risk, as locations are less important than knowing whether or not a crab was recaptured.

The collective evidence indicates that the spawning sanctuary is effective in allowing a considerable fraction (approximately 70\%, Lipcius et al. 2003) of the blue crab spawning stock that enters the sanctuary to spawn during the reproductive period in Chesapeake Bay. Furthermore, our estimate of the sanctuary's effectiveness is likely an underestimate because females tagged outside the sanctuary might move inside the sanctuary during migration to the spawning grounds and, therefore, would not be susceptible to the fishery. This would reduce the probability of recapture for crabs tagged outside the sanctuary and would lower the relative risk of recapture, therefore underestimating the effectiveness of the sanctuary. 


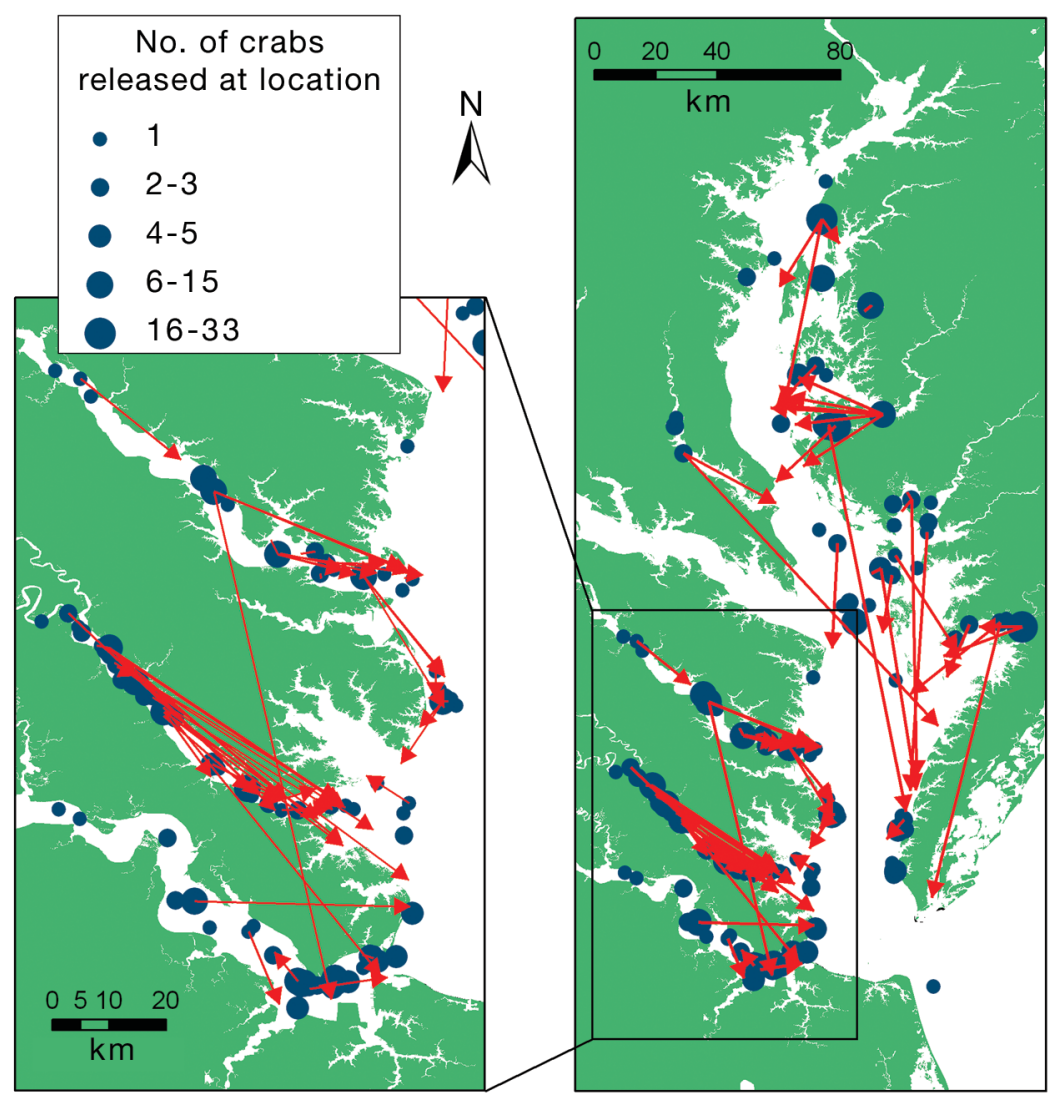

Fig. 3. Callinectes sapidus. Release locations of mature females tagged outside spawning sanctuary in Chesapeake Bay between 1 June and 15 July 2002, 2003, and 2004. Lines with arrows indicate recapture locations of individual crabs

tures of blue crabs tagged inside and outside 2 small spawning sanctuaries located at inlets along the Outer Banks of North Carolina along the Western Atlantic Ocean. The proportions recaptured from the different locations were approximately equal, indicating that the relatively small spawning sanctuaries offered little protection to the blue crab spawning stock in that system. The ineffectiveness of these sanctuaries was likely due to their small size (1798 ha and 3539 ha) relative to the movement patterns of adult females (Anonymous 2004, Medici 2004).

Our findings provided further evidence for the migration of adult female blue crabs down the tributaries and mainstem of the bay towards the spawning grounds during late spring and summer. Although the mean distance traveled did not vary between crabs tagged inside and outside the sanctuary, individuals tagged inside the sanctuary were at large for a significantly longer time than those tagged outside the sanctuary. This suggests that even though crabs in the sanctuary may be captured by the fishery, they remain in the system for a longer period of time and therefore are more likely to spawn than crabs outside the sanctuary.

There was no apparent relationship between the distance to the sanctuary border and the probability of recapture for crabs released inside or outside of the sanctuary, suggesting that degree of protection does not depend critically on location within the sanctuary. This further supports the idea that the sanctuary is of a proper design and large enough, relative to the movements of females, to protect females within its borders. It is likely that the crabs released inside the sanctuary migrated further south for spawning and remained in the sanctuary area.

This is the only known study that has demonstrated the use of relative risk as a tool to assess the effectiveness of a marine reserve. Tag-return data have, however, been used to compare percent recapture between animals tagged inside and outside of reserves (Rowe 2001, Medici 2004). Rowe (2001) tagged American lobster Homarus americanus inside and outside of 2 small reserves in Newfoundland, Canada. Only 0 to $19 \%$ of lobsters tagged inside the reserve were recaptured by the fishery, as opposed to a 12 to $72 \%$ recapture rate of lobsters tagged in areas open to the fishery (Rowe 2001). Medici (2004) compared the percentage recap-
Our estimates of directions and distances of travel were likely influenced by the distribution of fishing effort. There is very little information, however, on the amount of fishing effort in Chesapeake Bay and on relative amounts of effort in different areas. In addition, movement patterns in a portion of the bay (the spawning sanctuary) cannot be observed when the sanctuary is in effect (since fishing is not allowed). Nonetheless, the overall pattern of movement (down the tributaries and down the bay) conforms to what has been inferred in past studies (Fiedler 1930, Van Engel 1958, Turner et al. 2003, Aguilar et al. 2005).

The mean size of the recaptured crabs was significantly larger than the mean size of crabs that were not recaptured. This could be related to size-selective exploitation due to the use of cull rings in the commercial fishery (Lipcius \& Stockhausen 2002). Cull rings are used in crab pots throughout the tributaries and mainstem of the lower portion of Chesapeake Bay and in the mainstem of the upper portion of the bay, thus allowing smaller adult females (i.e. $<140 \mathrm{~mm}$ carapace width) to escape pots, while larger females are captured in the crab pots (Guillory \& Hein 1998). 


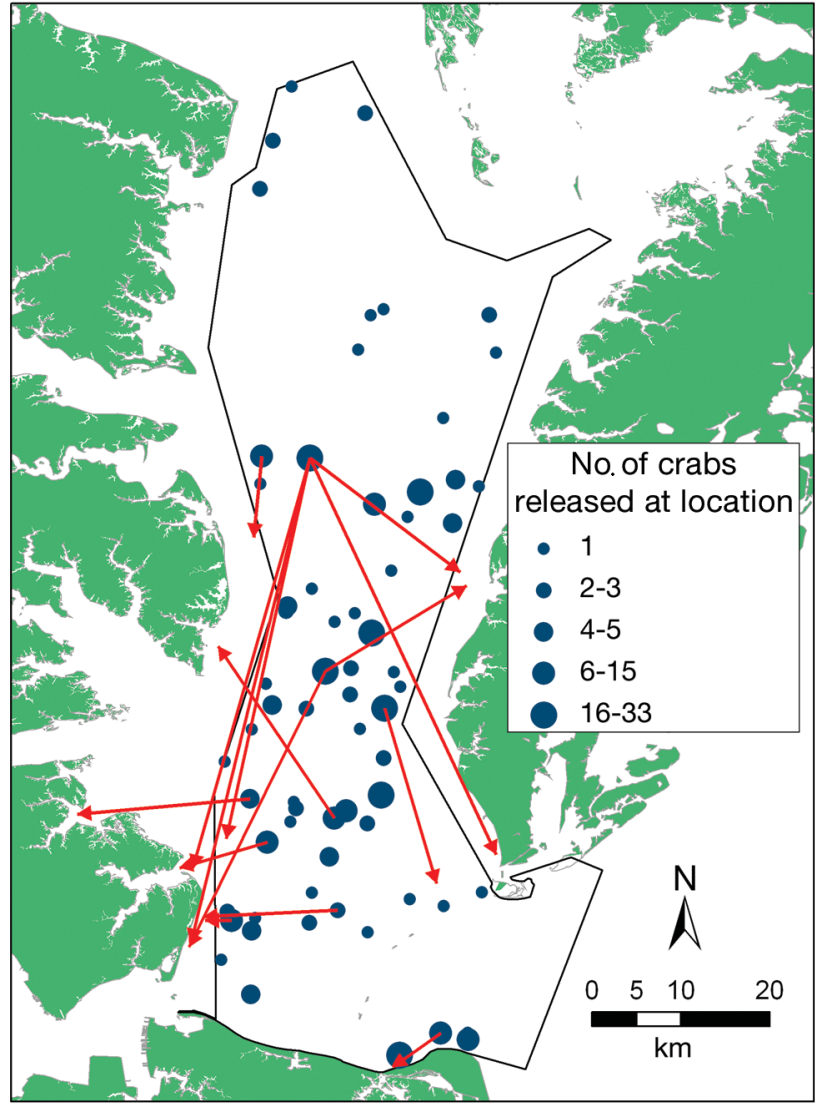

Fig. 4. Callinectes sapidus. Release locations of mature females tagged inside spawning sanctuary in Chesapeake Bay between 1 June and 15 July 2002, 2003, and 2004. Lines with arrows indicate recapture locations of individual crabs. Black outlined area represents blue crab spawning sanctuary

Table 2. Callinectes sapidus. Mean size (carapace width) and standard error (SE) of adult female blue crabs tagged and released outside and inside spawning sanctuary between 1 June and 15 July. Sample sizes (N) vary somewhat from those in Table 1 because some crabs were not measured

\begin{tabular}{|llcccc|}
\hline \multirow{2}{*}{ Year } & Location & $\mathrm{N}$ & Mean size $(\mathrm{mm})$ & $\mathrm{SE}$ & $\mathrm{p}$ \\
\hline $\mathbf{2 0 0 2}$ & Outside & 162 & 137.1 & 1.2 & 0.719 \\
& Inside & 33 & 136.1 & 3.0 & \\
$\mathbf{2 0 0 3}$ & Outside & 124 & 141.4 & 1.3 & 0.228 \\
& Inside & 43 & 138.5 & 1.9 & \\
$\mathbf{2 0 0 4}$ & Outside & 209 & 148.4 & 1.4 & $<0.0005$ \\
& Inside & 207 & 138.8 & 1.1 & \\
\hline
\end{tabular}

The sizes of crabs tagged inside and outside of the sanctuary did not differ significantly in 2002 and 2003, but in 2004 females tagged inside the sanctuary were significantly smaller than those tagged outside (Table 2). If smaller females had a lower probability of recapture by the fishery (Guillory \& Hein 1998, Lipcius \& Stockhausen 2002), then the relative risk esti- mates may have been biased in favor of sanctuary effectiveness in 2004

Although the blue crab sanctuary is effective in protecting female crabs that have entered its borders, the sanctuary and various exploitation controls have not protected a sufficiently large fraction of the population (Seitz et al. 2001) to avert the $84 \%$ decline in spawning stock biomass (Lipcius \& Stockhausen 2002), sustained low abundances (Chesapeake Bay Stock Assessment Committee 2005), and low annual survival rates (Lambert et al. in press). There is thus a pressing need to enhance restoration efforts of the spawning stock for long-term, sustainable exploitation and population persistence of the blue crab in Chesapeake Bay. High fishing mortality of blue crab females outside the sanctuary likely precludes sufficient numbers of mature females from successfully migrating to the spawning sanctuary, therefore limiting the benefits of the seasonal closure. The current management regime must be altered to increase the numbers of mature females entering the spawning sanctuary, through a combination of extended spatial management zones encompassing migration corridors and nursery grounds, as well as effort reductions in fished areas. In addition, expansion of the sanctuary through November and into the upper bay would protect those females migrating from the upper parts of the bay (Turner et al. 2003, Aguilar et al. 2005), while expanding it through April and into the upper bay would protect females that have overwintered either in deep-water migration corridors or in the spawning grounds and will produce their first egg mass in the spring (Van Engel 1958, Millikin \& Williams 1984).

Acknowledgements. The authors are extremely grateful to the following research surveys for their assistance in tagging of crabs: VIMS Trawl Survey, MDNR Trawl Survey, ChesMMAP, CHESFIMS, and the Bay-wide Winter Dredge Survey. We specifically thank M. Seebo, N. Olmstead, K. Knick, K. Erickson, M. Montane, W. Lowry, L. Liguori, T. Mathus, C. Crippen, A. Halvorson, H. Brooks, A. Jestel, A. Hewitt, J. Ellis, P. Gerdes, J. Gartland, E. Brasseur, P. Lynch, C. Bonzek, R. Latour, D. Ward, J. Gibbs, L. Fegley, G. Davis, and T. Miller. We also thank D. Wilcox for assistance with GIS software and R. Chuenpagdee, R. Latour, and 2 anonymous reviewers for their comments on the manuscript. Funding was provided by the National Oceanic and Atmospheric Administration (NOAA) Chesapeake Bay Office principally under the project 'Tagging Studies of Blue Crabs in Chesapeake Bay' with analyses and report preparation funded by the 'Blue Crab Advanced Research Consortium' project. Finally, we are extremely grateful to the Honorable Senator J. H. Chichester, who provided legislative support for expansion of the sanctuary, to C. Failmezger and the Save the Blue Crab Foundation, who provided community support for expansion of the sanctuary, and to W. Pruitt, J. Travelstead and R. O'Reilly of the Virginia Marine Resources Commission for implementing the sanctuary regulation. This is contribution number 2716 of the Virginia Institute of Marine Science. 


\section{LITERATURE CITED}

Aguilar R, Hines AH, Wolcott TG, Wolcott DL, Kramer MA, Lipcius RN (2005) The timing and route of movement and migration of post-copulatory female blue crabs, Callinectes sapidus Rathbun, from the upper Chesapeake Bay. J Exp Mar Biol Ecol 319:117-128

Anonymous (2003) The blue crab 2003: Status of the Chesapeake population and its fisheries. Blue Crab Technical Work Group. Chesapeake Bay Commission, Annapolis, MD

Anonymous (2004) North Carolina blue crab fishery management plan. North Carolina Department of Natural Resources, Division of Marine Fisheries, Raleigh, NC

Attwood CG, Bennett BA (1994) Variation in dispersal of Galjoen (Coracinus capensis) (Teleostei: Coracinidae) from a marine reserve. Can J Fish Aquat Sci 51:1247-1257

Beets J, Friedlander A (1992) Stock analysis and management strategies for red hind, Epinephelus guttatus, in the U.S. Virgin Islands. Proc Gulf Caribb Fish Inst 42:66-79

Beets J, Friedlander A (1998) Evaluation of a conservation strategy: a spawning aggregation closure for red hind, Epinephelus guttatus, in the U.S. Virgin Islands. Environ Biol Fish 55:91-98

Bertelsen RD, Cox C (2001) Sanctuary roles in population and reproductive dynamics of Caribbean spiny lobster. In: Kruse GH, Bez N, Booth A, Dorn MW and 6 others (eds) Spatial processes and management of marine populations. AK-SG-01-02, University of Alaska Sea Grant, Fairbanks, AK, p 591-605

Bonzek CF, Latour RJ, Gartland J (2004) Chesapeake Bay Multispecies Monitoring Program. Chesapeake Bay Fisheries Research Program Symposium Report 2003. NOAA Chesapeake Bay Office, Annapolis, MD

Brumbaugh RD, Sorabella LA, Garcia CO, Goldsborough W, Wesson JA (2000) Making a case for community-based oyster restoration: an example from Hampton Roads, Virginia, USA. J Shellfish Res 19:467-472

Chesapeake Bay Stock Assessment Committee (2005) 2005 Chesapeake Bay blue crab advisory report. NOAA Chesapeake Bay Office, Annapolis, MD

Chiappone M, Sealey KMS (2000) Marine reserve design criteria and measures of success: Lessons learned from the Exuma Cays Land and Sea Park, Bahamas. Bull Mar Sci 66:691-705

Chiappone M, Sluka R, Sealey KS (2000) Groupers (Pisces: Serranidae) in fished and protected areas of the Florida Keys, Bahamas and northern Caribbean. Mar Ecol Prog Ser 198:261-272

Churchill EP Jr (1919) Life history of the blue crab. Bull US Bureau Fish 36:91-134

Coleman FC, Baker PB, Koenig CC (2004) A review of Gulf of Mexico marine protected areas: successes, failures, and lessons learned. Fisheries 29:10-21

Cronin LE (1949) Comparison of methods of tagging the blue crab. Ecology 30:390-394

Daniel WW (1999) Biostatistics: a foundation for analysis in the health sciences. John Wiley \& Sons, New York

Davis GE, Dodrill JW (1980) Marine parks and sanctuaries for spiny lobster fishery management. Proc Gulf Caribb Fish Inst 32:194-207

Davis GE, Dodrill JW (1989) Recreational fishery and population dynamics of spiny lobster, Panulirus argus, in Florida Bay, Everglades National Park, 1977-1980. Bull Mar Sci 44:78-88

Delgado GA, Bartels CT, Glazer RA (2004) Translocation as a strategy to rehabilitate the queen conch (Strombus gigas) population in the Florida Keys. Fish Bull 102:278-288
Dugan JE, Davis GE (1993) Applications of marine refugia to coastal fisheries management. Can J Fish Aquat Sci 50: 2029-2042

Fiedler R (1930) Solving the question of crab migrations. Fish Gaz 47:18-21

Fischler KJ (1965) The use of catch-effort, catch-sampling, and tagging data to estimate a population of blue crabs. Trans Am Fish Soc 94:287-310

Fischler KJ, Walburg CH (1962) Blue crab movement in coastal South Carolina, 1958-59. Trans Am Fish Soc 91: $275-278$

Gitschlag GR (1986) Movement of pink shrimp in relation to the Tortugas sanctuary. N Am J Fish Manag 6:328-338

Guénette S, Pitcher TJ, Walters CJ (2000) The potential for marine reserves for the management of northern cod in Newfoundland. Bull Mar Sci 66:831-852

Guillory V, Hein S (1998) A review and evaluation of escape rings in blue crab traps. J Shellfish Res 17:551-559

Heslinga GA, Orak O, Ngiramengior M (1984) Coral reef sanctuaries for trochus shells. Mar Fish Rev 46:73-80

Hines AH, Wolcott TG, González-Gurriarán E, GonzálezEscalante JL, Freire J (1995) Movement patterns and migration in crabs: telemetry of juvenile and adult behaviour in Callinectes sapidus and Maja squinado. J Mar Biol Assoc UK 75:27-42

Joe M (2001) Stage-structured tag-return and capture-recapture models. PhD dissertation, North Carolina State University, Raleigh, NC

Jones CM, McConaugha JR, Geer PJ, Prager MH (1990) Estimates of spawning stock size of blue crab, Callinectes sapidus, in Chesapeake Bay, 1986-1987. Bull Mar Sci 46: 159-169

Judy MH, Dudley DL (1970) Movements of tagged blue crabs in North Carolina waters. Commer Fish Rev 32:29-35

Kassner J, Malouf RE (1982) An evaluation of 'spawner transplants' as a management tool in Long Island's hard clam fishery. J Shellfish Res 2:165-172

Lambert DM, Hoenig JM, Lipcius RN (in press) Tag-return estimation of annual and semi-annual survival rates of adult female blue crabs. Trans Am Fish Soc

Latour RJ, Brush MJ, Bonzek CF (2003) Toward ecosystembased fisheries management: strategies for multispecies modeling and associated data requirements. Fisheries 28: $10-22$

Lipcius RN, Stockhausen WT (2002) Concurrent decline of the spawning stock, recruitment, larval abundance, and size of the blue crab Callinectes sapidus in Chesapeake Bay. Mar Ecol Prog Ser 226:45-61

Lipcius RN, Stockhausen WT, Eggleston DB (2001a) Marine reserves for Caribbean spiny lobster: empirical evaluation and theoretical metapopulation recruitment dynamics. Mar Freshw Res 52:1589-1598

Lipcius RN, Seitz RD, Goldsborough WJ, Montane MM, Stockhausen WT (2001b) A deep-water dispersal corridor for adult female blue crabs in Chesapeake Bay. In: Kruse GH, Bez N, Booth A, Dorn MW and 6 others (eds) Spatial processes and management of marine populations. AKSG-01-02, University of Alaska Sea Grant, Fairbanks, AK, p 643-666

Lipcius RN, Stockhausen WT, Seitz RD, Geer PJ (2003) Spatial dynamics and value of a marine protected area and corridor for the blue crab spawning stock in Chesapeake Bay. Bull Mar Sci 72:453-469

Lipcius RN, Crowder LB, Morgan LE (2005) Metapopulation structure and marine reserves. In: Norse EA, Crowder LB (eds) Marine conservation biology: the science of maintaining the sea's biodiversity. Island Press, Washington, 
DC, p 328-345

McCay M (1988) Muddling through the clam beds: cooperative management of New Jersey's hard clam spawner sanctuaries. J Shellfish Res 7:327-340

McConaugha JR (1993) Tag-recapture study of the spawning stock of Chesapeake Bay blue crabs. Final Report to NOAA/NMFS for project: NA89EA-H-00060. NOAA Chesapeake Bay Office, Annapolis, MD

McGarvey R (2004) Estimating the emigration rate of fish stocks from marine sanctuaries using tag-recovery data. Fish Bull 102:464-472

Medici DA (2004) Scale dependent movements and protection of the female blue crab, Callinectes sapidus. MS thesis, North Carolina State University, Raleigh, NC

Miller TJ, Nye JA, Curti K, Loewensteiner D, Houde ED, Christman MC, Volstad JH, Sharov AF (2005) Abundance, distribution and diversity of Chesapeake Bay Fishes: results from CHESFIMS (Chesapeake Bay Fishery Independent Multispecies Fisheries Survey). Chesapeake Bay Fisheries Research Program Symposium Report FY 2004. NOAA Chesapeake Bay Office, Annapolis, MD, p 21-34

Millikin MR, Williams AB (1984) Synopsis of biological data on the blue crab, Callinectes sapidus Rathbun. FAO Fisheries Synopsis No. 138, NOAA Tech Rep NMFS 1, Washington, DC

Montane MM, Lowery WA, Austin HM (2004) Estimating relative juvenile abundance of ecologically important finfish and invertebrates in the Virginia portion of Chesapeake Bay, Project \# NA03NMF4570378, June 2003-May 2004. Annual Report to NOAA Chesapeake Bay Office, Annapolis, MD

National Research Council (2001) Marine protected areas: tools for sustaining ocean ecosystems. NRC, National Academy of Sciences, National Academy Press, Washington, DC

Newcombe CL (1943) Report of the Virginia Fisheries Laboratory of the College of William and Mary and the Commission of Fisheries for the period July 1, 1941-June 30, 1943. Division of purchase and printing, Richmond, VA

Oesterling MJ (1976) Reproduction, growth, and migration of blue crabs along Florida's Gulf Coast. Florida Sea Grant Publication. SUSF-SG-76-003, University of Florida, Gainsville, FL

Polacheck T (1990) Year round closed areas as a management tool. Nat Res Modeling 4:327-354

Prager MH (1996) A simple model of the blue crab, Call-

Editorial responsibility: Otto Kinne (Editor-in-Chief),

Oldendorf/Luhe, Germany inectes sapidus, spawning migration in Chesapeake Bay. Bull Mar Sci 58:421-428

Roberts CM, Polunin NVC (1991) Are marine reserves effective in management of reef fisheries? Rev Fish Biol Fish 1:65-91

Rowe S (2001) Movement and harvesting mortality of American lobsters (Homarus americanus) tagged inside and outside no-take reserves in Bonavista Bay, Newfoundland. Can J Fish Aquat Sci 58:1336-1346

Rowe S (2002) Population parameters of American lobster inside and outside no-take reserves in Bonavista Bay, Newfoundland. Fish Res 56:167-175

Rowley RJ (1994) Marine reserves in fisheries management. Aquat Conserv Mar Freshw Ecosyst 4:233-254

Rugolo LJ, Knotts KS, Lange AM, Crecco VA (1998) Stock assessment of Chesapeake Bay blue crab (Callinectes sapidus Rathbun). J Shellfish Res 17:493-517

Sandoz M (1943) Steps toward conservation in Chesapeake Bay. Virginia Fisheries Laboratory Contribution 15, Virginia Institute of Marine Science, Gloucester Pt, VA, p 1-6

Sandoz M, Rogers R (1944) The effect of environmental factors on hatching, moulting, and survival of zoea larvae of the blue crab, Callinectes sapidus Rathbun. Ecology 25:216-228

Seitz RD, Lipcius RN, Stockhausen WT, Montane MM (2001) Efficacy of blue crab spawning sanctuaries in Chesapeake Bay. In: Kruse GH, Bez N, Booth A, Dorn MW and 6 others (eds) Spatial processes and management of marine populations. AK-SG-01-02, University of Alaska Sea Grant, Fairbanks, AK, p 607-626

Southworth M, Mann R (1998) Oyster reef broodstock enhancement in the Great Wicomico River, Virginia. J Shellfish Res 17:1101-1114

Tagatz ME (1968) Biology of the blue crab, Callinectes sapidus Rathbun, in the St. Johns River, Florida. Fish Bull 67:17-33

Tegner MJ (1992) Brood-stock transplants as an approach to abalone stock enhancement. In: Shepherd S, Tegner M, Guzman del Proo S (eds) Abalone of the world: biology, fisheries and culture. Blackwell Scientific Publications, Oxford, p 461-473

Turner HV, Wolcott DL, Wolcott TG, Hines AH (2003) Postmating behavior, intramolt growth, and onset of migration to Chesapeake Bay spawning grounds by adult female blue crabs, Callinectes sapidus Rathbun. J Exp Mar Biol Ecol 295:107-130

Van Engel WA (1958) The blue crab and its fishery in Chesapeake Bay. Part 1: Reproduction, early development, growth, and migration. Commer Fish Rev 20:6-17

Submitted: October 19, 2005; Accepted: January 30, 2006

Proofs received from author(s): August 14, 2006 